\title{
Anti-OX40 Monoclonal Antibody IBI101
}

National Cancer Institute

\section{Source}

National Cancer Institute. Anti-OX40 Monoclonal Antibody IB/101. NCI Thesaurus. Code C158507.

An agonistic fully human anti-OX40 (tumor necrosis factor receptor superfamily member 4; TNFRSF4; CD134; OX40L receptor) with potential immune checkpoint inhibitory and antineoplastic activities. Upon administration, anti-OX40 monoclonal antibody IBI101 selectively binds to and activates OX40. Receptor activation induces proliferation of memory and effector T-lymphocytes and results in a T-cell-mediated immune response against tumor cells, which leads to tumor cell lysis. OX40, a cell surface glycoprotein and member of the tumor necrosis factor receptor superfamily (TNFRSF), is expressed on Tlymphocytes and provides a co-stimulatory signal that promotes both the proliferation and survival of activated T-cells. 